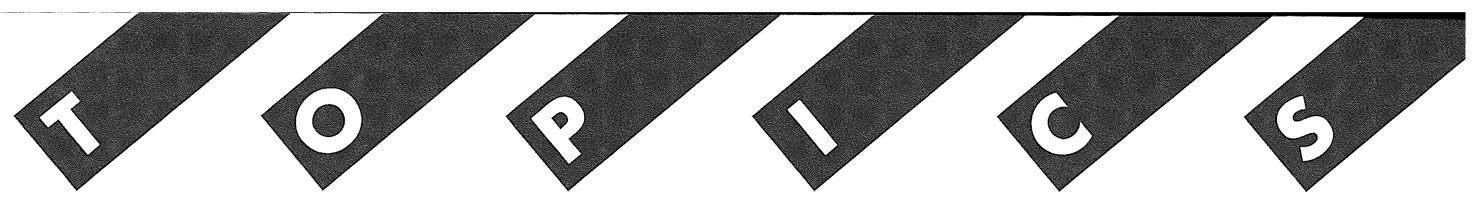

\title{
膵管胆道合流異常症における 最近のトピックス
}

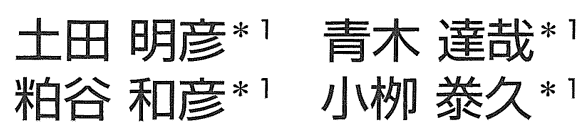

膵管胆道合流異常症（PBM）は、活性化された 膵酵素によって、持続的に胆道粘膜の傷害、再生 を繰り返す過程で、前癌病変を含む様々な粘膜変 化を生じ、高率に胆道癌を合併する。したがって、 一般にPBM と診断されれば、たとえ癌を合併し なくても、胆囊摘出あるいは肝外胆管切除などの 予防的手術が行われている。近年、診断技術の進 歩により、PBMにおいても、遺伝子変異を含めた 分子生物学的な解析がなされているが、各施設の 症例数がわずかなため、統一された見解は得られ ていない。本稿では、自験例の成績を含め、PBM の癌化過程に関する最近の知見について紹介する。

\section{$\mathrm{PBM}$ の癌化リスク}

蓮見らは、第 8 回日本荤管胆道合流異常研究会 で発表した全国アンケートの再評価を行い、PBM を合併しない胆道手術症例を natural control とし、 肝外胆管の拡張形態などの面から PBMにおける胆

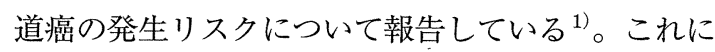
よると、胆汁うっ滞の少ない、あるいはほとんど ない非囊胞状症例（紡錘型、非拡張など）では、 胆管癌のリスクはnatural controlとの間に明らか な差を認めないことが指摘された。しかしながら、 肝外胆管非拡張例に扔ける分流手術（予防的胆管 切除）の是非については、古くから議論がなされ ているが、残念ながら未だに結論が出ていない2,3)。

\section{PBMの病理組織}

胆汁のうっ滞および㬸液の逆流による胆道内の持 続的な刺激によって、多彩な粘膜変化が見られる。

* 1 東京医科大学 外科学第三講座
われわれはPBMの胆囊病変に関して詳細な病理学 的検討を行った結果、ほとんどの症例で過形成を伴 い、また胆囊癌周囲の非癌部粘膜のみに化生・異形 成を認めたことより、PBM の癌化過程は、過形成一 異形成一癌という連続性によるものと考えている ${ }^{4,5)}$ 。 糸井らも、PBM 合併の胆囊癌と PBM を合併しない 通常胆囊癌の背景粘膜を検討し、通常型では幼若化 生上皮および幽門腺化生上皮が、PBM 合併例では 固有上皮および粘膜過形成の幼若部が前癌病変とし て重要であると報告しており ${ }^{6)}$ 、彼らも hyperplasia - carcinoma sequence を支持している7)。

\section{$\mathrm{K}$-ras codon 12 遺伝子変異}

近年、PBMにおいても癌遺伝子のひとつである $\mathrm{K}-r a s$ 遺伝子の変異が関与していることが報告され ている。自験例では、PBM胆囊癌 12 例中 4 例 (33\%) にK-ras変異を認めたが5)、諸家の報告で は41〜83\%とかなりバラッキがある(表1) ${ }^{9)}$ 。この 原因は、Sasatomi らが指摘しているように、 K-ras 変異の測定方法が一定でないこと、症例数が少な いことなどに起因している ${ }^{9)}$ 。表1に示すように、 過去の報告における検討症例数は、ほとんどが 10 前後であり、今後の検討が待たれる。

$\mathrm{PBM}$ の $\mathrm{K}-r a s$ 変異に関して注目すべき点のひと つは、固有上皮・過形成などの非癌部上皮において も変異を認めることであるが、大腸癌の腫瘍化の初 期あるいは膵炎の一部などでもしばしば同様の変異 を来すことがあり、この変異のみが発癌の直接的な promotorになっているわけではないと考えられる。

もうひとつの注目すべき点は、自験例において、 非癌部の胆道上皮の $\mathrm{K}-r a s$ 変異の出現頻度を見る と、小児と成人の間に、明らかな有意差を認めなか 
表 1 胆囊粘膜におけるK-ras codon 12遺伝子变異

\begin{tabular}{|c|c|c|c|c|c|c|}
\hline 報告者 （年） & 測定方法 & 過形成 & 化生 & 異形成 & 癌 & 備考 \\
\hline Hanada $ら$ (1996) & PCR-RFLP & & & & $3 / 6(50 \%)$ & Stage Iのみ \\
\hline Itoi $ら$ (1996) & PCR-RFLP & $0 / 5(0 \%)$ & & & $7 / 17(41 \%)$ & \\
\hline Iwase ら (1997) & $\begin{array}{c}\text { PCR-SSCP } \\
\text { direct sequencing }\end{array}$ & $5 / 14(36 \%)$ & & & $5 / 6(83 \%)$ & \\
\hline Matsubara ら (1997) & $\begin{array}{c}\text { PCR-SSCP } \\
\text { direct sequencing }\end{array}$ & $5 / 8$ & $63 \%) *$ & $3 / 4(75 \%)$ & & *過形成 - 化生 \\
\hline Tanno ら (1998) & $\begin{array}{c}\text { PCR-RFLP } \\
\text { direct sequencing }\end{array}$ & $2 / 15(13 \%)$ & & & $2 / 3(67 \%)$ & \\
\hline 自験例 (2000) & PCR-ELMA & $30 / 47(64 \%)$ & $12 / 43(28 \%)$ & $4 / 24(17 \%)$ & $4 / 12(33 \%)$ & \\
\hline
\end{tabular}

表2 胆震粘膜におけるp53遺伝子異常

\begin{tabular}{|c|c|c|c|c|c|}
\hline 報告者 （年） & 測定方法 & 過形成 & 異形成 & 癌 & 備考 \\
\hline Hanada ら (1996) & $\begin{array}{l}\text { overexpression } \\
\text { PCR-SSCP }\end{array}$ & & & $\begin{array}{l}4 / 6(67 \%) \\
3 / 6(50 \%)\end{array}$ & $\begin{array}{l}\text { Stage Iのみ } \\
\text { Stage Iのみ }\end{array}$ \\
\hline 船电ら (1997) & overexpression & $3 / 5(60 \%)^{*}$ & & $3 / 3(100 \%)$ & *過形成 · 化生 \\
\hline 横山ら (1998) & overexpression & $0 / 16(0 \%)$ & & $8 / 13(62 \%)$ & \\
\hline 自験例 (2000) & overexpression & $0 / 8(0 \%)^{* *}$ & & $9 / 12(75 \%)$ & **癌の背景粘膜 \\
\hline
\end{tabular}

ったことである ${ }^{5)}$ 。もし、加齢とともに胆道粘膜の 傷害が蓄積され、遺伝子変異の発生率が増加すると したならば、高齢になるにつれてK-ras 変異の発現 頻度は増加するはずである。しかしながら、今回の 結果から、膵液の逆流による慢性的な胆道粘膜の傷 害の期間と $\mathrm{K}-$ ras 変異の発現頻度は、必ずしも比 例しないことが示された。このような、年齢に伴う 遺伝子変異の解析を行っている報告は他にはないた め、この点に関しても今後の検討課題である。

\section{p53遺伝子変異}

前述の如く、 $\mathrm{K}-r a s$ 変異は腫瘍化の初期の段階 で起こるイベントとして位置づけられており、癌 化にはp53抑制遺伝子などの新たな遺伝子異常が 必要と考えられている。PBMのp53遺伝子異常の 測定方法には、異常蛋白の過㮃発現をみる方法と PCR-SSCPによる方法の 2 種類が報告されている (表2 $)^{5,10,11)}$ 。船电らは、過形成・化生上皮の 5 例中 3 例 $(60 \%)$ で異常を認めたと報告しているが、
横山らおよび自験例とも非癌部の粘膜では 1 例も p53 遺伝子変異を認めなかった。一方、Hanada ら の報告を含め、PBM の癌部では 50〜 100\%の範囲 でp53の遺伝子異常を認めておう、通常の胆囊癌 と同様に、PBM胆囊癌の癌化により直接的に関与 していることが示唆された。残念なことに、これ らの報告は $\mathrm{K}-r a s$ 変異に関するものよりも少なく、 十分な解析がなされているとは言い難い。

\section{おわりに}

乳癌、肺癌、大腸癌など症例数が多い癌種では、 遺伝子レベルでの解析が克明になされ、これらを ターゲットとした様々な遺伝子治療が臨床で行わ れるまでになっている。これに比べると、PBMの 癌化過程の解明は未だ黎明期にあり、 $\mathrm{K}-\mathrm{ras}$ およ びp53について検討がなされているだけである。 PBM は症例数が少ないため、共通した解析方法に よる全国規模のスクリーニングがきわめて重要に なってくるものと期待される。 
[文献]

1）蓮見昭武, 菅谷宏, 青木春夫. 先天性胆道拡張症, 膡 - 胆管 合流異常と胆道癌一アンケート集計から一. 胆と腪 16：753-757, 1995

2) Funabiki T, Matsubara T, Ochiai M, et al. Surgical strategy for patients with pancreaticobiliary maljunction without choledochal dilatation. Keio J Med 46 : 169172, 1997

3) Aoki $T$, Tsuchida A, Kasuya $K$, et al. Is preventive resection of the extrahepatic bile duct necessary in cases of pancreaticobiliary maljunction without dilatation of the bile duct? Jpn J Clin Oncol 31 : 107111,2001

4）小柳漛久, 吉松昭彦, 伊藤伸一, 他. 腪 - 胆管合流異常に 扔ける胆囊病変㧍よび胆囊粘膜の病理組織学的所見. 胆 道 $7: 510-517,1993$

5) Masuhara S, Kasuya K, Aoki $T$, et al. Relation between $\mathrm{K}$-ras codon 12 mutation and p53 protein overexpression in gallbladder cancer and biliary ductal epithelia in patients with pancreaticobiliary maljunction. J Hepatobiliary Pancreat Surg $7:$ 198-205, 2000.
6) 系井隆夫, 渡辺英伸, 粕谷和彦, 他. 胆䨣前癌病変の病理. 胆と蔶 $16: 1-12,1995$

7）横山直行, 渡辺英伸, 味烊洋一, 他. 胆囊癌における遺伝子 異常としての生物学的悪性度. 日外会誌 99：687-695, 1998

8) Obara $T$, Tanno $S$, Fujii $T$, et al. Epithelial cell proliferation and gene mutation in the mucosa of gallbladder with pancreaticobiliary malunion and cancer. J Hepatobiliary Pancreat Surg 6 : 229-236, 1999

9) Sasatomi E, Tokunaga O, Miyazaki $K$, et al. Precancerous conditions of gallbladder carcinoma : overview of histopathologic characteristics and molecular genetic findings. J Hepatobiliary Pancreat Surg $7: 556-567,2000$

10) Hanada K, Tsuchida A, Kajiyama G. Cellular kinetics and gene mutations in gallbladder mucosa with an anomalous junction of pancreaticobiliary duct. J Hepatobiliary Pancreat Surg 6：223-228, 1999

11）船电孝彦, 松原俊樹, 神野治. 膵 - 胆管合流異常におけ 万遺伝子異常. 消化器外科 20: 1255-1263, 1997
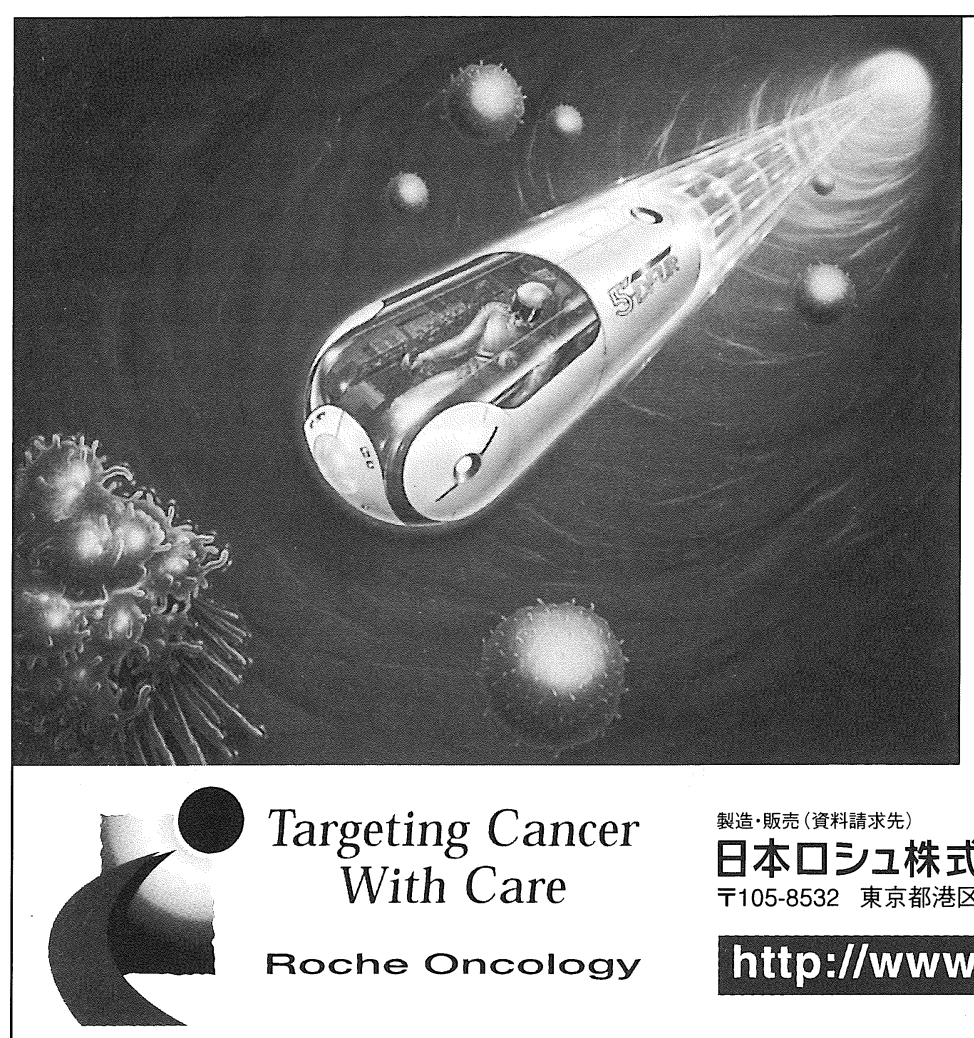

Targeting Cancer With Care

Roche Oncology

製造·販売 (資料請求先)

日本ロシュ株式会社 間合せTEL

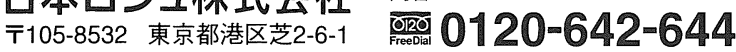
http://www.nipponroche.co.jp/ 